\title{
Service Gap of Selected Public and Private Commercial Banks in Bangladesh
}

\author{
Mst. Momena Akhter
}

Lecturer, Faculty of Business, ASA University Bangladesh

\begin{abstract}
The economy of a country is largely dependent on banking sector. In this case, Bangladesh is not exceptional. Both public and private banks play a vital role in the economy, making up one of the biggest providers of services in the Bangladesh economy. In the current banking environment, service quality is one of the main weapons, which enables the banks to differentiate from each other. It is said that service quality has become an important factor to survive and succeed in the banking sector. Hence, providing a better service quality is vital, as banks have to compete for customers. In this paper, the factors leading to the service provider gaps in case of selected public and private commercial banks have been identified and measured and it attempts to show the relationship between the provider gaps of these banks and the gap between expected service and perceived service (customer gaps). Two public commercial banks (Janata Bank Ltd., and Agrani Bank Ltd.) and two private commercial banks (Dutch Bangla Bank Ltd., and Prime Bank Ltd.) were selected for the purpose of the study. In this paper there is an endeavor to recognize whether the service provider gaps and the customer gaps are correlated and takes into consideration the problems of organizational quality gaps where the quality losses occur. This will help the management of these banks to know where the service gaps lie and how to close the gaps for providing quality service to their clients. This study shows that the overall service gap is higher in the public commercial banks in comparison to the private commercial banks. To remove this gap and to improve the overall service quality this paper has recommended some measures for both public and private commercial banks in Bangladesh.
\end{abstract}

Key Word: Service, Quality, Service gap, Expected Service, Perceived service, SERVQUAL, Bangladesh.

GEL Classification Code: M30; M31

\section{INTRODUCTION}

Managers in the service sector are under increasing pressure to demonstrate that their services are customer-focused and that continuous performance improvement is being delivered. Given the financial and resource constraints under which service organizations must manage it 
is essential that customer expectations are properly understood and measured and that, from the customer's perspective, any gaps in service quality are identified. This information then assists a manager in identifying cost-effective ways of closing service quality gaps and of prioritizing which gaps to focus on a critical decision given scarce resources.

While there have been efforts to study service quality, there has been no general agreement on the measurement of the concept. The majority of the work to date has attempted to use the SERVQUAL (Parasuraman et al., 1985; 1988) methodology in an effort to measure service quality (e.g. Brooks et al., 1999; Chaston, 1994; Edvardsson et al., 1997; Lings and Brooks, 1998; Reynoso and Moore, 1995; Sahnet et al., 2004).

One of the aims of this study involves identifying and measuring the factors leading to the service provider gaps in case of selected public and private commercial banks in Bangladesh. Another aim of this paper is to show the relationship between the provider gaps of these banks and the gap between expected service and perceived service (customer gaps). In the following, after a brief review of the service quality concept, the model of service quality gaps is demonstrated and then, after a discussion, major conclusions are derived.

\section{LITERATURE REVIEW}

The service sector is expanding at an increasing rate and is becoming intensely competitive (Chen, Gupta and Rom, 1994; Johnson, Dotson and Dunlap, 1988).Service can be defined as any activity or benefit that one party offers to another that is essentially intangible and does not result in the ownership of anything. Its production may or may not be tied to a physical product. A company's offerings often include some services (Lovelock Christopher, 2004).

The nature of most services is that the customer is present in the delivery process. This means that the perception of quality is influenced not only by the 'service outcome' but also by the 'service process' (Ghobadian Abby, Speller Simon \& Jones Matthew, 1994). Many researchers and authors define service qualities in different ways. Service quality is a measure of how well a delivered service matches the customers' expectations. Quality in service is very important especially for the growth and development of service sector business enterprises (Powell, 1995). Service quality is defined as how well the service meets or exceeds the customers' expectations on a consistent basis (Crosby, 1979; Parasuraman, Zeithaml and Berry, 1985). Parasuraman et al., Liljander, and Tore (1992) agreed that service quality is the difference between expectation and the performance of the service or the perception of the customer.

Among the contemporary instruments for measuring service quality, SERVQUAL has got attention by the researchers in various fields including insurance, bank, education, Information Technology (IT), etc. as it deals with users views regarding services (Parasuraman et al., 1985). This model is based on a comparison between the customers' expectations of the standard of service he/she will receive and his/her perception of the standard of service that is actually delivered. Furthermore, Parasuraman et al., see their service quality measurement model as one of the models that have been shown to enjoy a high degree of validity and stability. The model attempts to show the salient activities of the service organization that influence the perception of quality. Moreover, the model shows the interaction between these activities and identifies the linkage between the key activities of the service organization or marketer, which are pertinent to the delivery of a satisfactory level of service quality. The links are described as gaps or discrepancies; that is to say, a gap represents a significant hurdle to achieving a satisfactory level of service quality (Ghobadian et al., 1994).

The primary thesis of the model is that the service quality shortfall (i.e. Gap 5, the gap between customer service expectations and perceptions) is the result of a series of 
shortfalls within the service provider's organization i.e. Gap 1-4). Thus, improving the quality of service experienced by customers (i.e. closing Gap 5) requires diagnosing the causes of and correcting the internal deficiencies (i.e. Gap 1-4) (Parasuraman, 2004).

Luk and Layton (2002) developed the traditional model of Parasuraman et al. (1998) by adding two more gaps. They reflect the differences in the understanding of customer expectations by manager and front-line service providers and the differences in consumer expectations and service providers' perceptions of such expectations.

Alam M.M.D and Momotaz S.N. (2008) measured the Diagnostic Centers' expectations and perception about service of local customized software of Bangladesh. They found out the gap between the clients' expectations and perception using SERVQUAL model. They also showed the relationship between the five dimensions (reliability, responsiveness, assurance, empathy and tangibility) and client satisfaction.

In the study of service quality in the banking sector in Turkish banking, Yavas et. al., (1997) focused on the relationship between service quality on consumer satisfaction, complaint behavior and commitment. Their study found that overall service quality was a significant determinant customer satisfaction, complaint behavior and commitment.

Amin and Isa (2008) examined the relationship between service quality perception and customer satisfaction in Malaysian Islamic banking. They found that the relationship between service quality and customer satisfaction was significant.

\section{Methodology of the Study}

As the study is about measuring the service gap of public and private commercial banks, the population includes the customers of selected public and private commercial banks in Bangladesh. However two public commercial banks (Janata Bank Limited, and Agrani Bank Limited) and two private commercial banks (Dutch Bangla Bank Limited, and Prime Bank Limited) were selected for the purpose of the study. The total sample size has been set at 200, with 50 respondents representing each of the mentioned banks. Though the sample size is not representative part of the population, the present study might be focused on future study with big sample size. The sample size was selected by using simple random sampling approach which is based on easy accessibility of the sample.

The SERVQUAL approach of Parasuraman et al. (1985, 1996, 1988, 1991, and 1994) was demonstrated for identifying and measuring the service quality gaps. A structured questionnaire has been used to collect the data. The questionnaire has been developed in a way that reveals the respondent's response related to each of the independent variables. All the questions were taken into consideration for the regression model analysis. A linear regression model has been developed to measure whether the service provider gaps and the customer gaps are correlated.

The secondary data were collected from consulting various documents, reports, articles, case studies, books, and internet and so on. The collected data were analyzed keeping in mind the objective of the study. The period of study is January 2012 to Augusts 2012.

\section{Model of Service Quality Gaps}

There are seven major gaps in the service quality concept, which are shown in Figure 1. These seven gaps are described below:

Gap 1: Customer's expectation versus management perceptions

This gap occurs because of the lack of marketing research orientation, inadequate upward communication and too many layers of the management.

Gap 2: Management perceptions versus service specifications 
It happens because of inadequate commitment to service quality, a perception of feasibility, inadequate task standardization and absence of goal setting.

Gap 3: Service specifications versus service delivery

The third gaps takes place because of role ambiguity and conflict, poor employee-job fit and poor technology-job fit, inappropriate supervisory control systems, lack of perceived control and lack of teamwork.

Gap 4: Service delivery versus external communication

It arises from inadequate horizontal communication and propensity to over-promise.

Gap 5: The discrepancy between customers' expectations and their perceptions of the service delivered

Because of the influences exerted from the customer side and the shortfalls (gaps) on the part of the service provider, the fifth gap that is known as customer gap.

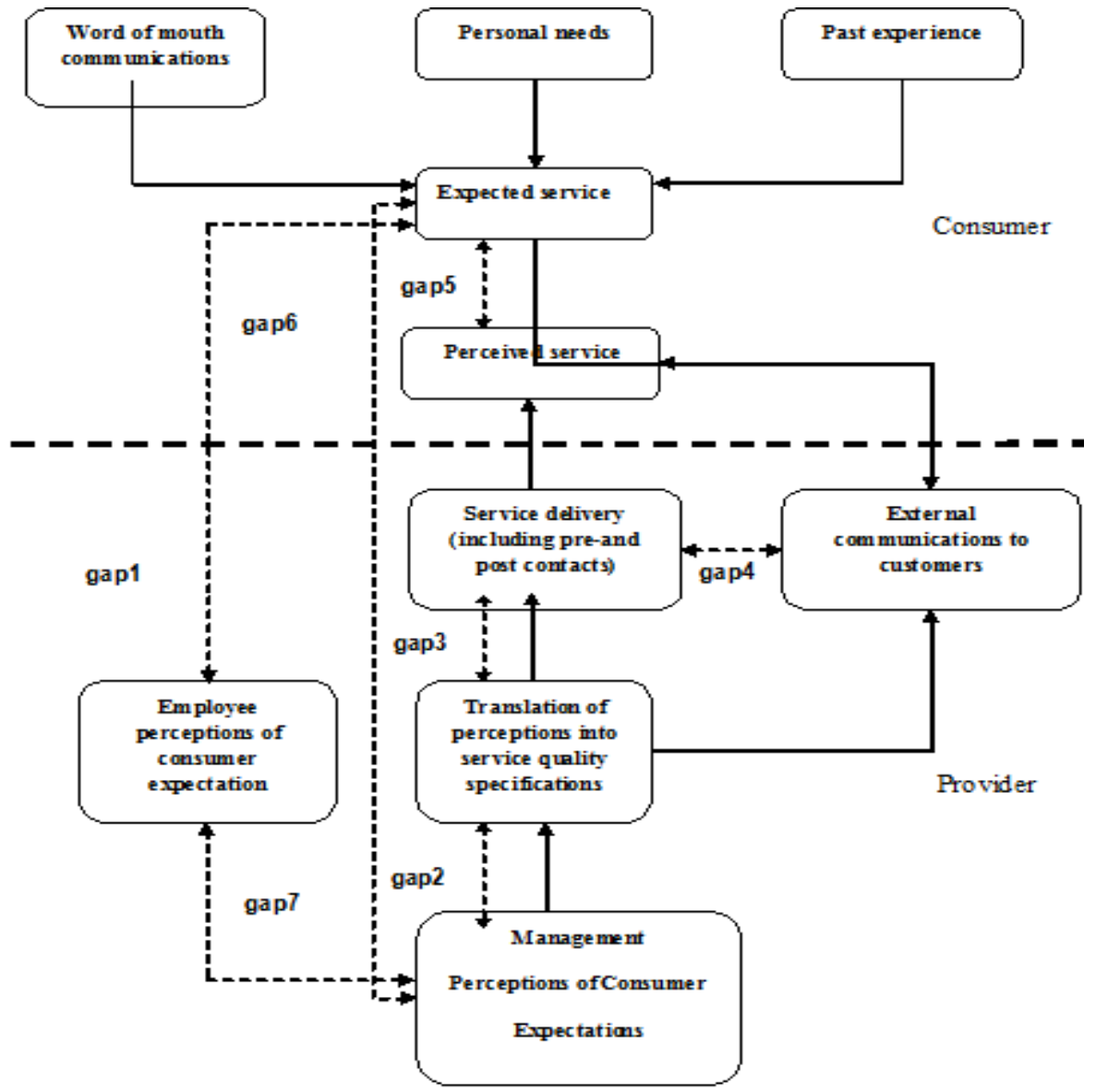

Source: (Parasuraman et al., 1985; Curry, 1999; Luk and Layton, 2002)

Figure1. Conceptual Model of Service Quality Gaps

Gap 6: The discrepancy between customers' expectation and employee perceptions

This gap is created because of the differences in the understanding of customers' expectations by front-line service providers

Gap7: The discrepancy between employees' perceptions and management perceptions 
The seventh gap happens because of the differences in the understanding of customers' expectations between managers and service providers.

The present study focuses on six provider gaps (Gap 1, Gap 2, Gap 3, Gap 4, Gap 6, and Gap 7) and also shows the relationship between these provider gaps and the customer gap (Gap 5).

\section{FINDINGS}

Past studies suggest that service provider gaps affect the customer gap i.e. the gap between customer expectation and customer perception of service. In this study also, a relationship between the provider gaps and customer gaps is reviewed. The relationship between the provider gaps (independent variables) and customer gap (dependent variable) has been detected and analyzed by using a linear regression analysis. In this analysis, the coefficient correlation indicates how strong the relationship is. Here both $\mathrm{t}$ value and significance designate the nature and importance of the relationship.

\section{Public Commercial Bank}

Descriptive Analysis:

Average gap score of seven gaps is 2.9883. In this study, gap 7 is appeared as the lowest gap in case of public commercial banks. This refers that management of the banks has frequent face-to-face contact with the customer contact employees. Though gap 1 is appeared as the 2nd lowest gap (2.91); still there exists a significant gap. This refers that the management is yet unable to understand the customer expectations properly. We see that insufficient marketing research is a major contributor to gap 1. Gap between Service quality specification and service delivery (gap 3) is found as the largest quality gap.

\section{Table 1: Descriptive Statistics}

\begin{tabular}{|l|c|c|c|c|}
\hline \multicolumn{1}{|c|}{ Research Items } & N & Mean & $\begin{array}{c}\text { Std. } \\
\text { Deviation }\end{array}$ & GAP \\
\hline $\begin{array}{l}\text { Managers perfectly know customer's } \\
\text { expectations (Gap 1) }\end{array}$ & 100 & 4.0900 & .95447 & 2.91 \\
\hline $\begin{array}{l}\text { Management perfectly set the } \\
\text { performance standard according to the } \\
\text { perception of service quality (Gap 2) }\end{array}$ & 100 & 3.9900 & .90448 & 3.01 \\
\hline $\begin{array}{l}\text { The service is provided perfectly } \\
\text { according to the set standards and } \\
\text { specifications (Gap 3) }\end{array}$ & 100 & 3.9000 & .87039 & 3.10 \\
\hline $\begin{array}{l}\text { Advertisement and other } \\
\text { communications perfectly reflect } \\
\text { services which are provided (Gap 4) }\end{array}$ & 100 & 4.0100 & .93738 & 2.99 \\
\hline $\begin{array}{l}\text { Employees give individual attention to } \\
\text { every customer (Gap 6) }\end{array}$ & 100 & 3.9700 & .83430 & 3.03 \\
\hline $\begin{array}{l}\text { Management of the bank has frequent } \\
\text { face-to-face contact with the customer } \\
\text { contact employees(Gap 7) }\end{array}$ & 100 & 4.1100 & .76403 & 2.89 \\
\hline Average Gap & & $\mathbf{4 . 0 1 1 6 6 6 6}$ & & 2.9883 \\
\hline
\end{tabular}

Source: Primary 
Empirical findings show that giving individual attention to every customer (gap 6) exerts a significant impact on service quality. It is the second largest internal gap of public commercial banks. This means that employees are unaware about customer expectations and customer relationship is not focused in the public banks. Lack of customer driven standard and poor visually appealing physical facilities of this bank, increase the customer dissatisfaction in a great extent. Score of gap 3, gap 4, and gap 7 are also very close to the score of largest gap. This indicates that there is a lack of coordination among the inter and intra departments of Public commercial Banks. That is why; large service gaps exist which decrease service quality and causes poor customer satisfaction.

Regression Analysis Model:

The regression equation is as follows:

Variation between expected service and perceived service (Customer gap)

$(\hat{Y})=b_{0}+b_{1} * X_{1}+b_{2} * X_{2}+b_{3} * X_{3}+b_{4} * X_{4}+b_{5} * X_{5}+b_{6} * X_{6}+$ error

Where,

$\mathrm{B}_{0}=$ Intercept, $\mathrm{X}_{1}=$ Gap 1, $\mathrm{X}_{2}=$ Gap 2, $\mathrm{X}_{3}=$ Gap 3, $\mathrm{X}_{4}=$ Gap 4, $\mathrm{X}_{5}=$ Gap 6, and $\mathrm{X}_{6}=$ Gap 7

$\mathrm{b}_{1}, \mathrm{~b}_{2}, \mathrm{~b}_{3}, \mathrm{~b}_{4}, \mathrm{~b}_{5}, \mathrm{~b}_{6}$ are the Coefficients of $\mathrm{X}_{1}, \mathrm{X}_{2}, \mathrm{X}_{3}, \mathrm{X}_{4}, \mathrm{X}_{5}$, and $\mathrm{X}_{6}$ respectively.

Table 2: Variables Entered/Removed (b)

\begin{tabular}{|l|c|c|c|}
\hline Model & $\begin{array}{c}\text { Variables } \\
\text { Entered }\end{array}$ & $\begin{array}{r}\text { Variables } \\
\text { Removed }\end{array}$ & Method \\
\hline 1 & $\begin{array}{r}\text { Gap7, Gap6, } \\
\text { Gap1, Gap4, } \\
\text { Gap2, } \\
\text { Gap3(a) }\end{array}$ & & \\
& & & Enter \\
\hline
\end{tabular}

Source: Primary

a All requested variables entered.

b Dependent Variable: Customer' expected and perceived service match with the bank ( Customer Gap)

From table 2, it is visible that the variables entered in the calculation of relationship between the provider gaps and customer gap. The dependent variable is the customer gap.

Table 3: Model Summary

\begin{tabular}{|l|c|r|r|r|l|l|}
\hline Model & $\mathrm{R}$ & $\begin{array}{c}\mathrm{R} \\
\text { Square }\end{array}$ & $\begin{array}{c}\text { Adjusted } \\
\text { R Square }\end{array}$ & $\begin{array}{c}\text { Std. Error } \\
\text { of the } \\
\text { Estimate }\end{array}$ & $\mathrm{F}$ & Sig. \\
\hline 1 & $.715(\mathrm{a})$ & .511 & .479 & .51953 & 16.183 & $.000(\mathrm{a})$ \\
\hline
\end{tabular}

Source: Primary

a Predictors: (Constant), Gap7, Gap6, Gap1, Gap4, Gap2, Gap3

Positive Value of coefficient correlation (R) indicates that there is a positive relationship between the independent and dependent variables. Value of $\mathrm{R}$ is 0.715 , which indicates there is a moderate relationship between the dependent variable (Variation between expected service and perceived service) and the independent (Gap1, Gap2, Gap3, Gap4, Gap6, and Gap7) variables considered at the model.

The value of coefficient of determination R2 is 0.511 and this specifies that $51.1 \%$ of the variation in the dependent variable be explained by the independent variables. That means 
$48.9 \%$ variation in the dependent variable is clarified by other external variables. The $\mathrm{f}$ value is 16.83 and it is more than significant value 0.000 . Thus the model has been accepted.

Table 4: Coefficients (a)

\begin{tabular}{|l|l|c|c|c|c|c|}
\hline \multicolumn{2}{|c|}{} & \multicolumn{2}{|c|}{$\begin{array}{c}\text { Unstandardized } \\
\text { Coefficients }\end{array}$} & $\begin{array}{c}\text { Standardized } \\
\text { Coefficients }\end{array}$ & & \\
\cline { 2 - 5 } \multicolumn{2}{|l|}{ Model } & B & Std. Error & Beta & t & Sig. \\
\hline 1 & (Constant) & 1.364 & .396 & & 3.441 & .001 \\
& Gap1 & .248 & .095 & .329 & 2.611 & .011 \\
& Gap2 & .054 & .086 & .068 & .628 & .532 \\
& Gap3 & .187 & .102 & .226 & 1.830 & .070 \\
& Gap4 & .019 & .068 & .025 & .278 & .781 \\
& Gap6 & .188 & .083 & .218 & 2.275 & .025 \\
& Gap7 & .055 & .073 & .058 & .754 & .453 \\
\hline
\end{tabular}

Source: Primary

a Dependent Variable: Customer's expected \& perceived service match with this bank (Customer Gap)

Analysis of co-efficient provides us which independent variables have a significant relationship with the dependent variable. So,

Variation between expected service and perceived service (Customer gap)

$(\hat{Y})=1.364+0.248 * \mathrm{X}_{1}+0.054 * \mathrm{X}_{2}+0.187 * \mathrm{X}_{3}+0.019 * \mathrm{X}_{4}+0.188 * \mathrm{X}_{5}+0.055 *$

$\mathrm{X}_{6}$

Where, $X_{1}=$ Gap 1, $X_{2}=$ Gap 2, $X_{3}=$ Gap 3, $X_{4}=$ Gap 4, $X_{5}=$ Gap 6, and $X_{6}=$ Gap 7

From the table it can be seen that only the significance level for Gap 1 (management's unawareness about customer's expectations) (0.011), and Gap 6 (employees unawareness about customer expectations) (0.025) are less than level of significance (0.05). Hence, there may have a significant relationship between the "Customer gap "and Gap 1 and Gap 6. But for all other variables, significance level is higher than 0.05 . So, we can conclude that there may not have any significant relationship between "Customer gap” and Gap 2, Gap 3, Gap 4, and Gap 7.

\section{Private Commercial Banks}

\section{Descriptive Analysis:}

The average gap score of seven gaps is 1.97 in case of the selected Private Commercial Banks. The score of smallest gap, Gap 1 (1.86) shows that the management has somewhat knowledge about the customer expectations. In contrast, gap between customer service quality specification and service delivery (gap 3) is found as the largest quality gap and gap between management perception \& service quality specification (Gap 2) is also very close to the score of largest gap.

Table 5: Descriptive Statistics

\begin{tabular}{|l|c|c|c|c|}
\hline \multicolumn{1}{|c|}{ Research Items } & N & Mean & $\begin{array}{c}\text { Std. } \\
\text { Deviation }\end{array}$ & Gap \\
\hline $\begin{array}{l}\text { Managers perfectly know customer's } \\
\text { expectations (Gap 1) }\end{array}$ & 100 & 5.1400 & .66697 & 1.86 \\
\hline
\end{tabular}




\begin{tabular}{|l|c|c|c|c|}
\hline $\begin{array}{l}\text { Management perfectly set the performance } \\
\text { standard according to the perception of } \\
\text { service quality (Gap 2) }\end{array}$ & 100 & 4.9100 & .76667 & 2.09 \\
\hline $\begin{array}{l}\text { The service is provided perfectly according to } \\
\text { the set standards and specifications (Gap 3) }\end{array}$ & 100 & 4.9000 & .58767 & 2.10 \\
\hline $\begin{array}{l}\text { Advertisement and other communications } \\
\text { perfectly reflect services which are provided } \\
\text { (Gap 4) }\end{array}$ & 100 & 5.1000 & .75879 & 1.90 \\
\hline $\begin{array}{l}\text { Employees give individual attention to every } \\
\text { customer (Gap 6) }\end{array}$ & 100 & 5.0100 & .74529 & 1.99 \\
\hline $\begin{array}{l}\text { Management of the bank has frequent face- } \\
\text { to-face contact with the customer contact } \\
\text { employees(Gap 7) }\end{array}$ & 100 & 5.1000 & .73168 & 1.90 \\
\hline Average Gap & & 5.0266666 & & 1.97 \\
\hline
\end{tabular}

Source: Primary

The issue of how to match employees' perception and customers' expectations in the organization is important difficulty (gap 6) for the Private Commercial Banks. It appears that, it is a little bit challenging to educate and make qualify the personnel to understand the customers' need and expectation from the bank.

Apparently, the internal gaps-gap 4, and gap 7 may be seen as minor. But here still exists some problems, which cause the service quality to deteriorate. So, management is expected to take corrective measures as par the reports.

Regression Analysis:

From table 6 , it is visible that the variables entered in the calculation of relationship between the provider gaps and customer gap. The dependent variable is the customer gap.

Table 6: Variables Entered/Removed(b)

\begin{tabular}{|l|c|c|r|}
\hline Model & $\begin{array}{c}\text { Variables } \\
\text { Entered }\end{array}$ & $\begin{array}{c}\text { Variables } \\
\text { Removed }\end{array}$ & Method \\
\hline 1 & GAP7, & & \\
& GAP3, & & \\
& GAP2, & & Enter \\
& GAP4, & & \\
& GAP1, & & \\
& GAP6(a) & & \\
\hline
\end{tabular}

Source: Primary

a All requested variables entered.

b Dependent Variable: Customer' expected and perceived service match with the bank (Customer Gap)

Table 7: Model Summary

\begin{tabular}{|l|c|r|r|r|r|r|}
\hline Model & $\mathrm{R}$ & $\begin{array}{c}\mathrm{R} \\
\text { Square }\end{array}$ & $\begin{array}{c}\text { Adjusted } \\
\text { R Square }\end{array}$ & $\begin{array}{c}\text { Std. Error of } \\
\text { the Estimate }\end{array}$ & $\mathrm{F}$ & Sig. \\
\hline 1 & $.686(\mathrm{a})$ & .471 & .437 & .43088 & 13.801 & $.000(\mathrm{a})$ \\
\hline
\end{tabular}

Source: Primary 
a Predictors: (Constant), Gap7, Gap3, Gap2, Gap4, Gap1, Gap6

Positive Value of coefficient correlation $(R)$ indicates that there is a positive relationship between the independent and dependent variables. Value of $\mathrm{R}$ is 0.686 , which indicates there is a moderate relationship between the dependent variable (Variation between expected service and perceived service) and the independent (Gap1, Gap2, Gap3, Gap4, Gap6, and Gap7) variables considered at the model.

The value of coefficient of determination R2 is 0.471 and this specifies that $47.1 \%$ of the variation in the dependent variable be explained by the independent variables. That means $52.9 \%$ variation in the dependent variable is clarified by other external variables. The $f$ value is 13.801 and it is more than significant value 0.000 . Thus the model has been accepted.

Table 8: Coefficients(a)

\begin{tabular}{|c|c|c|c|c|c|c|}
\hline \multirow[t]{2}{*}{ Model } & & \multicolumn{2}{|c|}{$\begin{array}{l}\text { Unstandardized } \\
\text { Coefficients }\end{array}$} & \multirow{2}{*}{$\begin{array}{c}\text { Standardized } \\
\text { Coefficients } \\
\text { Beta } \\
\end{array}$} & \multirow[t]{2}{*}{$\mathrm{t}$} & \multirow[t]{2}{*}{ Sig. } \\
\hline & & B & Std. Error & & & \\
\hline \multirow[t]{7}{*}{1} & (Constant) & 1.499 & .531 & & 2.824 & .006 \\
\hline & Gap1 & .216 & .081 & .251 & 2.650 & .009 \\
\hline & Gap2 & -.024 & .062 & -.032 & -.382 & .703 \\
\hline & Gap3 & .291 & .089 & .298 & 3.272 & .001 \\
\hline & Gap4 & .027 & .064 & .035 & .422 & .674 \\
\hline & Gap6 & .194 & .078 & .251 & 2.476 & .015 \\
\hline & Gap7 & .104 & .064 & .133 & 1.627 & .107 \\
\hline
\end{tabular}

Source: Primary

a Dependent Variable: Customer's expected \& perceived service match with this bank (Customer Gap)

Analysis of co-efficient provides us which independent variables have a significant relationship with the dependent variable.

So, Variation between expected service and perceived service (Customer gap)

$(\hat{\mathrm{Y}})=1.499+0.216^{*} \mathrm{X}_{1}-0.024 * \mathrm{X}_{2}+0.291 * \mathrm{X}_{3}+0.027 * \mathrm{X}_{4}+0.194 * \mathrm{X}_{5}+0.104 *$

$\mathrm{X}_{6}$

Where, X1= Gap 1, X2= Gap 2, X3= Gap 3, X4= Gap 4, X5= Gap 6, and X6= Gap 7

From the table it can be seen that the significance level for Gap 1 (management's unawareness about customer's expectations) (0.009), Gap 3 (Gap between service quality specification and service delivery) (0.001) and Gap 6 (employees unawareness about customer expectations) (0.015) are less than level of significance (0.05). Hence, there may have a significant relationship between the "Customer gap "and Gap 1, Gap 3 and Gap 6. But for all other variables, significance level is higher than 0.05 . So, we can conclude that there may not have any significant relationship between "Customer gap" and Gap 2, Gap 4, and Gap 7.

Comparative review of service quality gap of the selected Public and Private Commercial Banks:

The overall service gap is much higher in Public Commercial Banks in comparison to Private Commercial Banks. The overall service gap is 2.9883 in Public Commercial Banks, whereas it is only 01.97 in Private Commercial Banks. The picture may clearly be viewed in the following table: 


\begin{tabular}{|l|c|c|}
\hline Service gaps & $\begin{array}{l}\text { Public } \\
\text { Commercial } \\
\text { Bank }\end{array}$ & $\begin{array}{l}\text { Private } \\
\text { Commercial } \\
\text { Bank }\end{array}$ \\
\hline $\begin{array}{l}\text { Gap between customers' expectations and } \\
\text { management perceptions (Gap 1) }\end{array}$ & 2.91 & 1.86 \\
\hline $\begin{array}{l}\text { Gap between management perceptions and } \\
\text { service specifications (Gap 2) }\end{array}$ & 3.01 & 2.09 \\
\hline $\begin{array}{l}\text { Gap between service specifications and service } \\
\text { delivery (Gap 3) }\end{array}$ & 3.10 & 2.10 \\
\hline $\begin{array}{l}\text { Gap between service delivery and external } \\
\text { communication (Gap 4) }\end{array}$ & 2.99 & 1.90 \\
\hline $\begin{array}{l}\text { Gap between customer expectations and } \\
\text { employees' perceptions (Gap 6) }\end{array}$ & 3.03 & 1.99 \\
\hline $\begin{array}{l}\text { Gap between employee's perceptions and } \\
\text { management perceptions (Gap 7) }\end{array}$ & 2.89 & 1.90 \\
\hline Average gap & 2.9883 & 1.97 \\
\hline
\end{tabular}

Source: Primary

From the study it can be concluded that the internal (provider) gaps of Public Commercial Banks are higher than that of Private Commercial Banks. This refers that the service quality of Private Commercial Banks is better than that of the Public Commercial Banks. But the authority of Private Commercial Banks should be conscious of existing service gaps to ensure more quality service and customer satisfaction.

\section{LIMITATION OF THE STUDY}

The findings of this study can be generalized after taking into consideration certain limitations. A small number of respondents (50 for Janata Bank Ltd., 50 for Agrani bank Ltd., 50 for Dutch Bangla Bank Ltd., and 50 for Prime Bank Ltd.) from Dhaka city have been used in this study. The respondents were selected on the basis convenience. So, the samples may not represent the population of the country. Besides, there were time and financial constraints to perform the study. Finally, in this study the perception of the clients of the service of the banks have been focused, which may not perfectly represent the actual service gaps of these banks. So the future researchers are suggested to remember the limitations of the study in further research in this area.

\section{CONCLUSION \& RECOMMENDATIONS}

This research brings into light the service gaps present in selected private \& public commercial banks in Bangladesh. It also shows how the provider gaps impact customer gap. The public commercial banks are not meeting the ever-increasing demand of their clients. To survive in competition with private sector's bank, competitive and professional attitude is to be created in the mind of the employees of the public sector's banks. Proper training and education is to be provided to the employees of Public Commercial Banks. In that case the salary structure of the bank employees is to be enhanced in consistence with private sector's bank. If this structural adjustment is not done properly and timely, public sector's banks will suffer from liquidity crises that may lead to lose solvency in future.

From this study, we can learn that there is a huge gap in service providing process of the public commercial banks. To remove this gap, the overall organizational system should be 
changed and improved. Following criteria are recommended from clients' viewpoint to reduce the service gaps and increase customer satisfaction:

- The company mission should include a focus on customer-orientation.

- The banks should give more focus on internal marketing and interactive marketing to ensure the functional and technical quality of service.

- A strong relationship with existing customers prevents Gap 1 from occurring and companies are more able to understand the changing needs and expectations of their existing customer base.

- Employees have to express solidarity with the customer and have to be aware of customer expectations.

- Training and motivational programmes should be introduced to improve the employee skill.

- Quick Response System (QRS) should be adopted to minimize the service delivery time.

- The banks should adopt modern equipments and modern banking system such on line bank, ATM banking, Mobile banking, etc. to provide better service.

- The public sector's bank can differentiate them by focusing on reliability, resilience, and innovativeness in delivering the service, handling the emergencies, and ensuring the optimal efficiency and effectiveness of the service.

- The bureaucratic relationship between the management and front line personnel should be removed.

The study shows that the service quality of the Private Commercial Banks is satisfactory; still there is a huge gap between customer expectations and employees' perceptions. Besides that, still some clients are not satisfied with the service of this bank. So, it is high time the banks would give proper attention to the problem of employees' unawareness about customer expectations and improve its overall service quality.

- Top management of the banks must have a thorough commitment to service quality.

- The management should look not only at financial performance on a monthly basis, but also service performance.

- The banks have to be more conscious in building customer relationship through proactive and partnership marketing

- The standards of service-quality should be set appropriately high.

- The banks can differentiate their service by designing a better and faster delivery system.

- A well defined system should be developed for monitoring service performance and customer complaints.

- The banks must audit service performance, both their own and competitors on a regular basis.

- The banks should give special attention to "One Stop Service."

- Getting frontline employees to adopt extra-role behaviors and to advocate the interests and image of the firm to consumers, as well as take initiative and engage in conscientious behavior in dealing with customers can be a critical asset in handling complaints.

- Retail banking functions should be more expanded.

- The banks should give more focus on internal marketing (training and motivating employees to serve customers well) and interactive marketing (employees skill in 
serving the clients) because the customers judge service not only by its technical quality, but also by its functional quality.

\section{REFERENCES}

Alam M.M.D. and Momotaz S.N. (2008), 'Analysis of end users' expectation and perception of service quality of software service providers: An empirical study on Diagnostic Centers in Dhaka City', Dhaka, Bangladesh.

Amin, M., and Isa, Z., 2008. 'An examination of the relationship between service quality perception and customer satisfaction: A SEM approach towards Malaysian Islamic banking.' International Journal of Islamic and Middle Eastern Finance and Management, 1(3), pp 191-209.

Brooks, R.F., Lings, I.N. and Botschen, M.A. (1999), "Internal marketing and customer driven wave fronts", Service Industries Journal, Vol. 19, No. 4, pp. 49-67.

Chaston, I. (1994), "Internal customer management and service gaps within the UK manufacturing sector", International Journal of Operations and Production, Vol. 14, No. 9, pp. 45-56.

Chen, I., A. Gupta and W. Rom. (1994) 'A Study of Price and Quality in Service Operations', International Journal of Service Industry Management, 5(2), 23-33.

Crosby, P. B. (1979), 'Quality is free: The art of making quality certain.' New York: New American Library.

Curry, A. (1999), "Innovation in public service management", Managing Service Quality, Vol.9, No.3, pp. 180-190.

Edvardsson, B., Larsson, G. and Setterlind, S. (1997), "Internal service quality and the psychological work environment: an empirical analysis of conceptual interrelatedness", Service Industries Journal, Vol. 17, No. 2, pp. 252-63.

Ghobadian Abby, Speller Simon \& Jones Matthew, (1994) “Service Quality: Concepts \& Models", International Journal of Quality \& Reliability Management, Volume 11 Number 9, pp. 43-66.

Lewis, B.R. and Mitchell, V.W. (1990), "Defining and measuring the quality of customer service", Marketing Intelligence \& Planning, Vol. 8, No. 6, pp. 11-17.

Lings, I.N. and Brooks, R.F. (1998), "Implementing and measuring the effectiveness of internal marketing", Journal of Marketing Management, Vol. 14, pp. 325-51.

Linjander, Veronica and Tore Strandvik (1992),"The Relationship between Service quality and intentions." Pp. 77-98 in proceedings of the $2^{\text {nd }}$ workshop on quality management in services, Jos Lemmink and Paul Kunst (eds).Brussels, Belgium: European Institute for advanced Studies in Management.

Lovelock Christopher, Wirtz Jochen. (2004) "Service Marketing: People, Technology, Strategy", 5th edition, Pearson education (Singapore) Pte. Ltd.,pp 406-411.

Luk, Sh.T.K. and Layton, R. (2002), "Perception Gaps in customer expectations Managers versus service providers and customers", The Service Industries Journal,Vol.22, No.2, April, pp. $109-128$

Parasuraman A. et al, (1985), 'A Conceptual Model of Service Quality and Its Implications for Future Research.' Journal of Marketing, Fall, pp 41-50. 
Parasuraman A., Zeithaml V.A, and Berry L.L., 1988, "SERVQUAL:A multiple-Item Scale for Measuring consumer Perceptions of Service Quality", Journal of Retailing 64 (spring 1988), pp 12-40

Parasuraman, A., (2004), "Assessing and improving service performance for maximum impact: insights from a two-decade-long research journey", Performance Measurement and Metrics, Vol. 5, No. 2., pp. 45-52.

Powell, T C (1995), "Total Quality Management as Competitive Advantage: A Review and Empirical Study", Strategic Management Journal, Vol. 16, pp. 15-37.

Reynoso, J. and Moore, B. (1995), "Towards the measurement of internal service quality", International Journal of Service Industry Management, Vol. 6, No. 3, pp. 64-83.

Sahney, S., Banwet, D.K., and Karunes, S. (2004), "A SERVQUAL and QFD approach to total quality education: A student perspective", International Journal of Productivity and Performance

Yavas U., Bilgin Z. and Shemwell D. J., 1997, "Service Quality in the Banking Sector in an Emerging Economy: A Consumer Survey", International Journal of Bank Marketing, vol. 15. No. 6 pp. 217-223.

Zeithaml, V. A., Berry, L. L., Parasuraman, A., "Communication and Control Processes in the Delivery of Service Quality", Journal of Marketing, 52, April, 1998, p. 36. in: Tourism and hospitality management, no. 1., Faculty for Tourism and Hospitality Management Opatija, Opatija. 